\title{
Communication Mode Code
}

National Cancer Institute

\section{Source}

National Cancer Institute. Communication Mode Code. NCI Thesaurus. Code C93533.

A coded value specifying the form in which the entity is transmitted. 